\title{
The State, Urban Displacement and Land Rights in Nigeria
}

\author{
Chibuzor Chile Nwobueze, PhD \\ Department of History and Diplomatic Studies, \\ Ignatius Ajuru University of Education, \\ PortHarcourt, Rivers State \\ James Okolie-Osemene \\ Institute for Peace and Strategic Studies, \\ University of Ibadan, Nigeria. \\ Ndu John Young \\ Department of History and Diplomatic Studies, \\ Ignatius Ajuru University of Education, \\ Port Harcourt, Rivers State
}

\begin{abstract}
The issues of urban displacement and land rights question have become the attributes of modern Nigerian state. The Fourth Republic is characterised by the arrogation of land by government. The nationalisation of land remains a watershed in land matters across Nigeria. This is based on how such development precipitated the phenomenon of cities in crisis with attendant urban vulnerabilities and creation of informal settlements. The recurrent urban displacement across the country has aroused a sense of how the phenomenon of contesting the city has received inadequate scholarly attention. In fact, various works have not established the intersection between state's policies and urban crisis which raises a question of land rights in a nation that had customary land tenure prior to the 1978 Land Use Act. The demolition of so-called "illegal structures" has been a contentious issue owing to the fact that the process is usually characterised by controversies on whom or what determines an "illegal structure", and "illegal inhabitants". From Lagos to Owerri, Oyo, Ogun, Abia, Port Harcourt, to mention but a few extreme cases, where people living in the city and around waterfronts have been displaced; the issue of urban displacement remains prevalent. Using synthesised primary and secondary sources, this paper is a case study of state's leanings toward urban displacement. The government needs to review land laws and policies in order to promote urban cohesion, integration and cooperation from the various segments in the city especially the indigenous people rather than excluding and denying them access to the use of their land. The paper suggests that there is need to prioritise welfare and adequate compensation of identified real occupants of the affected structures as well as resettling the people residing at informal settlements. This paper concluded by asserting that, in order to prevent or mange conflicts and urban crisis, urban development or urban renewal projects should be carried out through a participatory approach and with appropriate resettlement programme for the occupiers or inhabitants of the proposed area or structure remarked for demolition or renewal
\end{abstract}

Keywords: Government, demolition, urban displacement, land rights, illegal structures.

\section{INTRODUCTION}

Recent events across the country show that the magnitude of population displacement in Nigeria has increased tremendously considering the contexts in which people are displaced and the growing number of displaced people has also grown many folds (Ibeanu, 1998). These 
have manifested as a result of ethno-religious conflicts, oil spills and environmental degradation, resource control agitations, communal land related violence, the Boko Haram saga, kidnapping for ransom and now the state-urban renewal induced displacement that aimed at relocating illegal inhabitants or to demolish illegal structures. The foregoing sources of displacement made Ibeanu (1998) to argue that eradicating or managing the problems demands that the state must always rise above the interests of social groups, forging consensus and acting as a guarantor of the security of every group within its jurisdiction.

The Fourth Republic is characterised by the arrogation of land by the federal and state governments. The nationalisation of land remains a watershed in land matters across Nigeria. This is based on how such development precipitated the phenomenon of cities in crisis with attendant urban vulnerabilities and creation of informal settlements. The recurrent urban displacement across the country has aroused a sense of how the phenomenon of contesting the city has received inadequate scholarly attention. In fact, various works have not established the intersection between state's policies and urban crisis which raises a question of land rights in a nation that had customary land tenure prior to the 1978 Land Use Act. The demolition of socalled "illegal structures" has been a contentious issue owing to the fact that the process is usually characterised by controversies on whom or what determines an "illegal structure", and "illegal inhabitants". From Lagos to Owerri, Oyo, Ogun, Abia, Port Harcourt, to mention but a few extreme cases, where people living in the city and around waterfronts have been displaced; the issue of urban displacement remains prevalent. The most prominent example of urban factor in crisis and crisis management in Nigeria comes from Rivers state where Right Honourable R. O. Amaechi led Rivers State Government's urban renewal programme threatened the relative harmonious inter-group relations among the divers ethnic group. The plan to demolish all the water fronts in Port Harcourt largely occupied by the Ijo speaking people over the years in an effort to curb criminal violence currently threatening the goals of sustainable development in the Niger Delta. Against the background of riverine/upland dichotomy which inspired the agitation for the creation of Port Harcourt state, the Ijo challenged the programme on the basis that it will slow socioeconomic development in the hardest-hit developing riverine communities. This raises certain fundamental questions as to what rationale or template is applied by government officials to declare a structure or settlement by traditional people "illegal" and at which stage of the city's development. Most of the displacement is usually hinged on the need to transform the urban areas. Agbaje (2013:321) noted that urban renewal has always resulted into displacement of people from their residential and economic base, with remarkable factors like "the need to create new sets of states through territorial disaggregation, election of new party set of elite 2 into government, as well as the need to embark on major environmental and infrastructural development, such as road, rail construction, drainage, airport, markets." By implication, the state has been the hub of issues arising from urban displacement and land rights which affect its citizens. In fact, the advent of urbanisation has remained one of the main sources of internal displacement owing to the need for expansion of cities and towns across the country to accommodate new projects that would enhance development.

Some of these projects can be in the form of development infrastructure, construction of hospitals and educational institutions, building of markets and motor parks, construction of power lines in line with urban electrification, road construction and expansion, construction of flyovers and overhead bridges, dredging of rivers in cities, development of infrastructure for oil activities, among others.

According to Chekol (2017) increase in expense of labour also brought pressure to economise land including natural capital and the product flows produced by the natural product. Land 
rights can be promoted in various ways. The actualisation of human rights in nations is intrinsically a collaborative endeavour that demands the active involvement of policy makers, civil society, community and religious leaders among others (Patel and Tyrer, 2011; Ishay, 2004). This makes it pertinent for this study considering the significance of land rights to the management of urban displacement.

The Land Use Act is a legal framework of ownership and use of land in Nigeria. Nigeria's land use law is traceable to the Rent Panel Report of 1976 which agreed that lack of immediate availability of land for use when required by stakeholders contributed to the obstacles to economic development and national progress; a situation that made the then Supreme Military Council to set up a Land Use Panel (Obasanjo, 1978:3). This explains why land is regarded as a vital instrument for political and economic concerns of the state (Chekol, 2017). The Land Use Act is a radical departure from precolonial land appropriation and different from what land ownership used to be in that era when ownership of land was the exclusive preserve of the king, with some privileges given to the chiefs, while individuals held parcels of land in trust for the community in some villages (Ogunniyi, 2016:357). The customary land tenure was highly effective to the extent that the Owa Clan (now in Ika North East Local Government Area, Delta State) restricted Agbor's right over the land used as trenching ground as revealed by the District Officer during the colonial era (NAI/B.P.1/1237/1939).

The promulgation of the Land Use Decree (now Land Use Act) granted government at all levels the right to assign or lease undeveloped land to people, and provided that the rural dwellers and urban residents have a right to use the land and also compensated if they require to give their land to government. However, this policy remains ironical in reality as recent events in contemporary Nigerian society showed that rural dwellers, owners of urban land, and occupants of land for industrial, institutional, and other purposes, have lost the portions of land they developed and occupied to the government's interest of using such land. This development has manifested in some cases without proper compensation or resettlement of the victims despite government's assurances at the onset/initial stage of land policy.

Since the promulgation of the land use Act, various indigenous people have been dispossessed of their land by successive governments that capitalised on developing projects for urbanisation with insufficient or no compensation. This has had adverse impact on the human rights of the victims and further explains "hostility and fear in social life" (Dollard 1938).

\section{METHODOLOGY}

The study employed the social surveyed research design through which primary and secondary data were implored in order to examine state's leanings toward urban displacement. Nigeria's urban bias scenario has been revealed by available data on how over 2 million people lost their homes and land to compulsory land acquisitions as at 2006, the eviction of more than a million people in Port Harcourt by oil companies, as well as the eviction of more than 500,000 people in Abuja since 2003. Most of these scenarios were occasioned by urban renewal projects and expansion works aimed at transforming Nigerian cities with little or no consideration for the less privileged that are victims of urban induced forced eviction.

\section{LITERATURE REVIEW}

Studies are replete with issues on state, ethical issues in urbanisation, urban challenges and land rights (Ilo, 2016; Musa and Abah, 2016; Okene and Uadiale, 2016; Ibrahim, 2016). However, most of these studies did not adequately capture urban bias and state's leanings toward urban displacement which occasioned illegal structure and illegal inhabitants controversies in Nigeria. Abuja, which hosts many government institutions, has been seen as 
the hub of forced evictions since 1990s owing to what Levan and Olubowale (2014:388) described as "shifting government policies towards the area's original inhabitants and laws governing the FCT's 8,000 square kilometres perpetuate social inequality and discrimination."

Apart from being an entity with territory, government and population, the state is the small organisation of the people who apply the use of force to secure obedience (Owolabi, 1999). In the Nigerian state, the use of force to enforce obedience manifests in the issuance of order by government to people described as illegal occupants or structures in urban areas. According to Ukase (2016), a common variable used to address urbanisation issues is the proportion of the total population of the area, either a nation, state, city, or town and the number of inhabitants remains significant in this regard. In his work on ethical issues in urbanisation, Ibrahim (2016) identified the impact of growing world population on urbanisation considering how the world has become more urban in the 21st Century than it was in the 1960s, as rural population has been overtaken by urban population. This trend is obvious. The high rate of rural-urban migration in many countries explains why more people now reside in urban areas as people consistently search for more sources of livelihood to actualise their human potential.

Similarly, Ilo (2016), underscored that unemployment is a social problem in most parts of Africa, to the extent that youth now migrate to cities in search of gainful employment especially in their bid to get white collar jobs. The high standard of living in urban areas like Port Harcourt, Owerri, Enugu, Lagos, Abuja, Kano, Benin City, Jos and many others also attract people to the city. According to Hove et al (2013:3), "the relatively high concentration of social services and potential employment opportunities in urban areas, together with the glamour of city life, are important factors attracting rural people to cities." Albert (2003:58) identified the "speedy taking over of open public spaces in West African cities like Lagos and Abidjan by the underclass who usually function as street hawkers, pickpockets, drug dealers, touts" among others. This explains why most of these people easily become tools in the hands of criminals or enemies of the government.

Land tenure is the study of the relationship between men in the use and control of land resources (Oluwasanmi, 1966). This is the social aspect of land relations which determines and regulates the manner at which people own and access land for their productive use. In addition, land rights are inalienable entitlements to access land through inheritance, mortgage, lease and donation, without any intimidation or limitation. Land rights are not complete until the owner has the freedom to use a portion of land for any purpose at any point in time without any obstacle or litigation.

The need for equal rights made the people in Tanzania to use discourse of haki sawa to press for constitutional change and as means of engaging people in statutory reform and implementation of the Land Acts (Dancer, 2015:148). This equal rights to land access can enhance equity and stability of the society. Agwu, Amasiatu and Onuoha (2010:148) highlight the features of land rights in Nigeria thus, that both the Land Use Act and customary do not confer a woman the right to use, control or transfer land; splitting of land; discrimination of aliens from owning or controlling land as well as the politicisation of land claims. As seen from the aforementioned characteristics, it can be argued that land rights are not gender sensitive. The control of land has led to unusual pressure on land, even when some of those involved may not necessarily utilize it in a productive way to the benefit of mankind. According to Anene (1956:6), the increase of pressure on land has always been a source of discomfort to those affected. The inaccessibility to land across Nigeria has been caused by the existence of nonpeople oriented land law (Agwu, Amasiatu and Onuoha, 2010:147). This is due to 
discriminatory role of the land use law which is not gender sensitive and also hampers usufructural right that would have promoted agribusiness.

Land has been described as the most concrete representation of property, which should be classified as part of the protectable rights (Amankwah, 2007). Socio-economic rights are protectable rights. Land rights are rooted in changing economic and political structures as well as the interpretation and transformation of meanings associated with access to common property resources (Bassett, 1993:16). The relevance of land rights explains why land owners have mineral rights so as to protect their interest (Lamp and Stolz, 2015:436). Given that land is generally accepted as the most precious of all commodities and its use and control has been the major determinant of the nature and structure of human societies and government since time immemorial (Udeke, 1995:45), most land related policies often affect citizens of a nation. Unfortunately, the regulatory efforts of government often negates the principles of rights guarantees as being the first to clear, plant or build on a land does not guarantee ownership. Obviously, land is a symbol of identity. Alidri (2016:5) has this to say about land in Uganda, thus:

Land (angu or nyaku) was considered a gift from the creator (Adro). It comprises the soil, water, animals, forests, hills and mountains, and valleys and plains, and rivers and streams. A mystical relationship existed between the clan and land. The narratives held the belief that resource management was intertwined with traditional religion and that the misuse of resources caused the wrath of the gods and ancestral spirits.

Land was regarded as a common resource in pre-colonial Angola, with a system of communal possession in which any member of the community had the right to cultivate parcels of land occupied by the community (Foley, 2007:6).

In The Republic of Vanuatu, constitutional guarantees provide that the rules of custom shall form the basis of ownership and use of land (Articles 73\&74), and later strengthened by 2001 the Customary Land Tribunal Act which makes it illegal to alienate land (Jowitt, 2004:3). This is because land use is linked to a people's history and culture for continuity through time and space (Alidri, 2016:3). The foregoing reveals that custom is the regulatory framework of land tenure with constitutional backing, thereby giving the indigenous people the opportunity to appropriate land for different uses.

However, in the case of Nigeria, in colonial Lagos where there was customary land tenure, especially around the second half of Nineteenth Century, women needed to exercise constant vigilance to prevent men from encroaching on their rights to landed property; and notable was the case of Rokosi and Mary Mary Macaulay who went to colonial court in order to protect their right over land (Mann, 1991:695). This move was aimed at preventing the imminent threat of losing their landed property. After the Colonial Masters granted independence to the people, land was taken over by the government.

It is instructive that the 1902 Mineral Ordinance stated that lands in the protectorate were vested in the chief of the local communities in trust for the communities and also provided that in case of lands that belonged to the native community, the lease was to be granted by the chief with the approval of the High Commissioner. It further provided for the payment of compensation for damages on crops and buildings and a certain percentage of fees, rents and profit tax was payable to the land owners (Mangvwat, 1982 in Udeke, 1995:45). The foregoing is not obtainable in the current land laws regime which does not adequately address the aspirations and needs of land owners to the extent that compensation is not guaranteed. Thus, this raises a question of land rights in the context of justice and ethical issues of humanity. 
In Igbo society, land is regarded as the domain of the earth goddess, a place to make a living and the most important asset to the people who are usually given the opportunity to gain rights over land (Iwuagwu, 2008:7). Similarly, the acquisition and possession of land is "often an indicator of class and position" like Angola where land tenure issues are related to broader questions of equity and governance enactment of with Land Law 1992 (Law 21-C/92) protecting local community land rights (Foley, 2007:5). Equity in this sense has to do with how land relations affect land rights.

\section{CONCEPTUAL AND THEORETICAL EXPOSITION ON URBAN DISPLACEMENT AND LAND RIGHTS}

An urban center is a relatively large, dense and permanent settlement of socially heterogeneous individuals (Wirth, 1938 cited in Onoja, 2016). An urban center is an area with social amenities and hosts people from all walks of life, different nationalities and ethnic groups, than rural areas that have little amenities and host majority of indigenous people. Most urban communities are more populated than rural areas which do not have high population rates. Industries and government's institutions have large footprints in urban areas. This has made urban areas record traffic jams and congestion along various roads linking highways despite the construction of dual carriage roads. A notable attribute of urban areas is the use of public spaces by different classes of people and sometimes serve as sites of political protests or mobilisation of the masses especially middle class and the underclass in cities to challenge the decision of the state on crucial national issues like the use of the Gani Fawehinmi Freedom Square in Ojota Lagos as a gathering and mobilisation zone in January 2012 (Okolie-Osemene, 2017).

Urbanisation is regarded as the process of movement of people or process of human to the agglomerations in multinational settlements of relatively substantial size with features like population, law and order, efficient and planned housing schemes, infrastructural facilities such as good road, electricity, functional public health, planned environment/sanitation, schools, water systems, modern communication facilities, industries, markets and many others (Jibril and Abah, 2016). Urban displacement refers to a situation where inhabitants of landed property in the urban area are forced to leave their places of abode or settlements in the urban areas to other places they did not plan to reside in. This type of displacement is usually common in new states, developmental states or cities that are initiating new projects. Such displacement also occurs when new leaders or administration emerge in the affected areas. A notable attribute of directive to relocate is government's proclivity for problematising the use of the affected places as residential areas.

As far as the state is concerned, urban displacement can be classified as forced or involuntary migration. This is based on the fact that the phenomenon causes sudden migration in search of another place of abode. It is a manifestation of what Ibeanu (1998) described as force-subjectmigration reasoning. Implicit in this is the idea that force (war, conflict, drought, etc.) being an external factor affecting a person (subject) acts as a push factor leading to a rational, albeit coerced, decision to relocate. In essence, this urban displacement or eviction is far from having any linkage with positive motive to search for more livelihoods that would make life better for those affected.

Urban displacement is a phenomenon that is not only occasioned by conflicts or natural disasters but also caused by the state through urbanization policies. Contrary to the work of Ibeanu (1998), which highlights the causes of displacements like ethnic conflict, war, and drought, it is noteworthy that many are forced to relocate by government order. Most times, 
the available alternatives offered by the government or found by the victims cannot be said to be their own original decision. However, it should be noted that urban displacement in the context of government's plan to demolish illegal structures and relocate illegal inhabitants has more to do with push factors considering city development agenda rather than pull factors that do not necessarily concern the people that have to migrate to other places in this regard. This type of displacement has different spatial dimensions like the order by the governor for occupants of a community or settlement to relocate to a new area mapped out for habitation, a new estate, new neighbourhood village, or even an order for traders to vacate their shops along roads in the city.

Theoretically, this article is anchored on urban bias theory, which focuses on the political power of urban elite, who influence the state to channel resources to the cities and exploit the peasantry, who are geographically dispersed, disorganised, and subject to the "free-rider" problem despite their large numbers (Lipton 1977; Weede 1996 cited in Jenkins and Scanlan, 2001:723). At last, the peasants are usually left at the receiving end considering how some of them who live in areas that attract government development or foreign investors are usually displaced, particularly those living around slums, shanties, illegal structures among others. For instance, Okene and Uadiale (2016:325) reveal that the phenomenon of land rights question which has the state and foreign investors as actors has manifested in the competition for African land and resources that now include countries in Asia with large populations of Arab nations that have abundant petro-dollars and other countries that are equipped with biofuel processing technology.

\section{RESEARCH RESULTS: CASES OF URBAN DISPLACEMENT}

The 1999 Constitution retained the vexing issue of the Land Use Act in Section 315 (d) and the Act passed in 1978 as the Land Use Decree under Obasanjo's regime has angered communities especially the marginalised minorities (Ihonvbere, 2000:97). Countless number of people has been displaced by government's demolition of illegal structures in many parts of the country particularly federal and state governments. This section presents the nature and conflict impacts of such displacement.

As a symbol of national pride, not many people are aware that the praises people pour out on Abuja, the Federal Capital Territory (FCT), for its clean city streets, relatively reliable electricity, and large middle class comes with a price (Levan and Olubowale, 2014). This price has manifested in the displacement of many groups and indigenous people for such urbanisation to be achieved over time. Most of these people have been pushed out of the main city to communities at the outskirts of the city where it will likely take many years before development gets there. In Lagos, Owerri, Aba and Port Harcourt for instance, many have suffered and are still suffering from the pain of urban displacement and abuse of their right to land. Since 2006, reports by different media sources reveal that roughly 2 million people had lost their homes and land to compulsory land acquisitions. More than 1.2 million people have been evicted from the Port Harcourt area to allow for development of the oil and gas industries, and since 2003 the government has evicted more than 800,000 people in the capital, Abuja.

Most times, one of the first steps taken by government is to map out an area for demolition, and followed by issuance of ultimatum for people to relocate. However, not in all cases that victims are compensated. The next stage is the arrival of bulldozers escorted by heavily armed security forces to protect workers on site in case of any attack by the people. Both eviction and demolition of structures by government are usually backed by the engagement of security 
operatives in protecting people executing the order to avoid attack or aggression by the displaced citizens.

The cases of demolition in Lagos have shown that purchase of land is not an antidote after all. For instance, a victim of demolition at Minanuel Estate revealed that owners of the houses bought the land where the houses were built from the indigenes (Omooni le) who have been inhabiting Ogombo ever since their forefathers settled there (Akhigbe, 2016). The statement by Olakunle Bakare, the leader of one of the five families that originally owned the land is noteworthy as far as displacement and land rights are concerned, that government grabs land belonging to people because many are not aware of their right, even as government should not be seen as exclusive owner of land (Akhigbe, 2016).

As the spokesperson of the Nigeria Slum Informal Settlement Federation of Lagos State pointed out: "Government is not working with us to make Lagos a mega city but inflicting suffering on us" (Hanson, 2016). The statement was made to protest the plan to displace occupants of the water front communities across the state which has recorded a surge in criminal activities in recent times.

Demolitions as seen in most Nigerian cities have created what Levan and Olubowale (2014) described as housing insecurity in land laws and inconsistent policies. The market-driven economy of Nigeria lacks properly regularised land ownership or allocation system and this made urban poor to cater for their own accommodation, thereby "leading to the multiplication of slums and informal housing as the urban poor could only afford causing sub-standard houses" (Adekola, Allen and Tinuola, 2017:17). In fact, some residents of slums in urban areas have been implicated in criminal activities and accused of creating insecurity in the cities.

Categories of displaced people and purposes of demolition

\begin{tabular}{|c|c|c|}
\hline Purpose of demolition & Victims/groups & $\begin{array}{l}\text { Locations } \\
\end{array}$ \\
\hline $\begin{array}{l}\text { Urban renewal/road } \\
\text { dualisation }\end{array}$ & Traders & $\begin{array}{l}\text { Traders' shops at Ijaiye } \\
\text { housing estate, Jakande estate, } \\
\text { Pen Cinema, Agege in Lagos, } \\
\text { homes and shops in Aba, Oyo } \\
\text { town, Owerri, Edo and others. }\end{array}$ \\
\hline To eradicate crime & $\begin{array}{l}\text { People living in city } \\
\text { slums/settlements }\end{array}$ & Shanties/slums in many cities \\
\hline Crime and insecurity & Waterfront communities & $\begin{array}{l}\text { Structures at waterfronts } \\
\text { including Otodo Gbame } \\
\text { community, Lagos where } \\
\text { more than } 4,700 \text { people were } \\
\text { displaced and others in Rivers }\end{array}$ \\
\hline Urban renewal & Estate residents/estate developers & $\begin{array}{l}\text { About } 5,000 \text { housing units in } \\
\text { Minanuel estate Abuja were } \\
\text { demolished, Olokonloa } \\
\text { Gardens estate Lagos, }\end{array}$ \\
\hline $\begin{array}{l}\text { To stop encroachment on } \\
\text { government's land }\end{array}$ & House owners/residents & $\begin{array}{l}\text { Gbagyi Villa Community } \\
\text { Kaduna }\end{array}$ \\
\hline $\begin{array}{l}\text { To build institutions, } \\
\text { barracks or oil } \\
\text { installations, construct } \\
\text { roads, bridges or drainage }\end{array}$ & Farmers, land owners, & $\begin{array}{l}\text { Residential areas and } \\
\text { Farmlands in urban areas }\end{array}$ \\
\hline
\end{tabular}

Source: Compiled by the authors from observation and media reports 


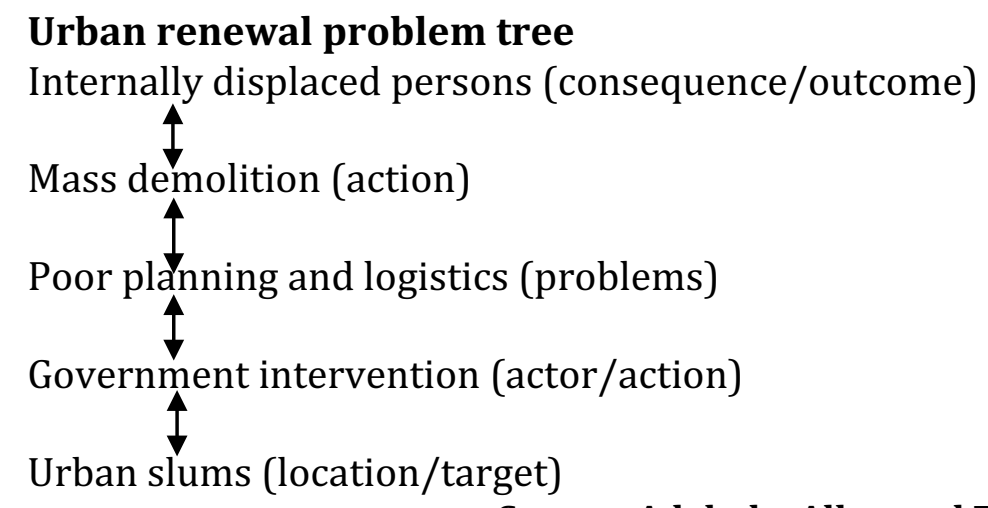

Source: Adekola, Allen and Tinuola (2016).

As seen from the above table and problem tree, the purposes of demolition which climax in displacement of victims are urban renewal, eradication of urban crime and construction of institutions or roads. The attributes of mass demolition which leads to displacement are poverty, congestion, high crime rate, urban decadence, unemployment and poor housing (Adekola, Allen and Tinuola, 2016), due to hopelessness affecting residents in urban slums, estates and other quarters in the city usually caused by government's inability to either plan relocation or compensate the victims before or after demolition.

\section{DISCUSSION WITH POLICY RECOMMENDATIONS}

The land use law has become controversial because some people support the divesting of landowners without compensation by insisting that land is a free gift of God and so nobody should claim money for it, without remembering that much land was paid for by sweat and blood in first settlement, first clearing, conservation, and conquests or securing land (The Guardian, 2007:35). It is a mind boggling development as far as land right issue is concerned. The argument against customary land tenure, as noted by Okonkwo (2013:23), that "land became very exorbitant; more difficult to acquire even for the government, with land speculation and profiteers", cannot be said to have been addressed by government's land use law which even denies people right to make productive use of land.

However, as things are not what they seem, the purported rights expected to be preserved have consistently been denied or violated by the same law. Controversies surrounding the law explains why, thousands of lives have been lost and property worth billions of naira destroyed in inter-family, inter-communal and inter-ethnic wars over land since the enactment of the law; thereby portraying the Land Use Decree as a negation of human rights owing to deprivation and the losers emerging at the end of the whole event (The Post Express, 2000:6). Therefore, a repeal of a number of legislation including the Land Use Act of 1978, and the Petroleum Act of 1969, which disposes communities of their land, and by so doing, attenuate the pervasive penury in the Niger Delta will guarantee the freedom from want and fear, which are fundamental to human dignity. It is striking that the devastating aspect of the Land Use Decree on Nigerians is that those who are forced to relinquish their land for the public good cry home with empty or near empty hands (The Guardian, 2007:35). After the decree, the people lost land, and were left with brute labour which undermined agricultural production and food security because it cuts the bond of ownership that had motivated individuals into the hard work of manual agriculture in the past (The Post Express, 2000:6).

The occurrence of urban displacement has become one of the sources of crisis in Nigerian cities as people suddenly lose their places of abode due to emergence of new governments or new policies by serving governments aimed at what they call urban renewal, environmental rescue mission or programmes to create green surroundings in the cities. The issue of human rights 
violations during demolition and displacement of people cannot be downplayed. Demolition of such structures violates people's right to shelter and also abuses their human dignity. Even the use of security operatives is a source of human rights violation because victims are sometimes harassed and even beaten by the security men that are supposed to protect them. This clearly poses an obstacle to public trust and confidence in the security forces. Confidence is further undermined by continuing human rights violations such as extra- judicial killings and sexual violence. With that mindset, trust and confidence are seldom found nor freely granted. These factors are now seen to be damaging the country's social fabric and it's potential for sustainable development.

The fact that various governments through the ministries of Federal Capital Territory, physical planning, works and housing now set up demolition squad makes it pertinent to also establish a resettlement squad without playing politics with it. What to do with the displaced should be a priority of those implementing urban renewal programmes to provide adequate housing with basic amenities even before embarking on forced eviction or demolition of the illegal structures. This will save the nation from expending time and money in countering crimes that would arise from the displacement of people which has the capacity of driving them into hopelessness.

The federal and state governments as well as other relevant authorities should adopt more humane strategy in pursuing urban renewal agenda by partnering with stakeholders such as Town Planning Authorities, Association of Building Artisans of Nigeria (ASBAN), Landlords association, Shelter Watch and other non-governmental organisations to address the problems of illegal structures without forcefully displacing the inhabitants of affected places. The provision of new sites with structures for habitation will prevent people from suffering heart attack on hearing about demolition order and provide a viable way of life considering the fact that the gap between the privilege and the less privileged has increased since 2010 more than in the past due to the war of supremacy between unemployment and inflation. The Millennium Development Goals report is of particular concern, "without sufficient employment opportunities, many young people grow discouraged and worthless." Given that Nigeria is signatory to international conventions that provide for adequate housing, the government should invest largely in the area of community development and human security and avoid forcefully evicting people because women, children, old people and even retirees who are no longer in active employment are affected.

Obviously, the lack of proper city planning causes urban displacement, vacuum in several fronts ranging from security to livelihoods; rising high cost of living is one of the factors encouraging informal settlements. Inadequate compensation for the demolition of residents' structures remains a problem associated with demolition by government. The government needs to review land laws to promote urban reintegration which cannot be achieved when the groups that contributes to the development of industries and commerce are socially excluded. However, there is need to prioritise welfare and empowerment of identified real occupants of the affected structures as well as resettling the people residing at informal settlements. Empowered people are also more productive than and not restive as neglected people in the society.

\section{CONCLUSION}

This study has shown that urban displacement in Nigeria is a phenomenon that promotes forced and involuntary migration with attendant abuse of land rights at the detriment of occupants of landed property. Sufficient evidence suggests that the most debilitating demolitions are those involving shops and residential houses as seen in many towns 
considering the attendant loss of shelter and sources of livelihood. This is because demolition of a man's house or shop is worse than fire razing down the building considering the possibility of rebuilding on the same land if the destruction involves fire incident. This article argues that the purpose of demolition, urban renewal or construction of public facilities, any demolition should be done after resettlement of the occupants of the affected structures in decent places of abode. The government should realise that forcing people out of their land or places they have paid for businesses without creating alternative solution to the problem of illegal structures rather portrays the policy makers as the enemies of the people. In the Niger Delta, there is a saying, "He who takes food out of your mouth is the one who kills you". With the context of the situation outlined and explained, countering strategies for transforming the socio-economic and political tensions and for sustainable development will require democracy without discrimination; participation and people-centred development agenda as well as sustainable human security framework to address the human security challenges responsible for "poverty-induced rural/urban migration".

The moment is ripe to access strategic ways in which human security and human development can be further incorporated into the urban management and transformation process. This will provide most people the opportunity to be empowered.

\section{References}

Adekola, P. O., Allen, A. A. and Tinuola, F. R. 2017. Socio-economic and health implications of urban renewal on internally displaced persons in Ogun State, Southwestern Nigeria. Journal of Internal Displacement 7 (1): 16-30.

Agbaje, E. B. A. 2013. Modernisation, urban renewal and the social cost of development. Mediterranean Journal of Social Sciences 4 (10): 318-324.

Agwu, K., Amasiatu O. G. and Onuoha, O. U. 2010. Land rights characteristics and access to land: Implications on food security in Nigeria. Journal of Environmental Issues and Agriculture in Developing Countries, 2 (2\&3): 146-156.

Akhigbe, N. 2016. Tearful Christmas as victims of Olokonla Gardens Estate demolition recount ordeal. Business Day December 25. http://www.businessdayonline.com/tearful-christmas-victims-olokonla-gardens-estatedemolition-recount-ordeal/

Albert, Isaac 0. 2003. The Concept of Security in the Context of Urban Crimes and Segregation in West Africa. In Fourchard, L. and Albert, I. O. Eds. Security, Crime and Segregation in West African Cities since the 19th Century. Paris/Ibadan: Karthala/IFRA. Pp. 53-69.

Alidri, A. 2016. Traditional wisdom in land use and resource management among the Lugbara of Uganda: A historical perspective. SAGE Open July-September: 1-13.

Amankwah, H. A. 2007. Traditional values and modern challenges in property law. Journal of South Pacific Law, 11 (1): 18-38. http://www.paclii.org/journals/f]SPL/vol11no1/pdf/Amankwah.pdf

Anene, M. 1956. The oil palm economy of the Ibibio farmer. Ibadan: Ibadan University Press.

Bassett, T. J. 1993. Introduction: the land question and agricultural transformation in Sub-Saharan Africa. In T. Bassett \& D. E. Crummey. (Eds.), Land in African agrarian systems: 3-31. Wisconsin: The University of Wisconsin Press.

Chekol, B. 2017. Contending views on land tenure system in Ethiopia: Historiographical essay. African Journal of History and Culture 9 (1): 1-6.

http://www.academicjournals.org/journal/AJHC/article-full-text-pdf/43C363562790

Dancer, H. 2015. Women, land \& justice in Tanzania. Suffolk, UK: James Currey.

Foley, C. 2007. Land rights in Angola: poverty and plenty. HPG Working Paper. Humanitarian Policy Group/Overseas Development Institute.

Hanson, V. 2016. Group shut down Lagos Assembly over slums demolition. Blackface, http://blackface.com.ng/2016/10/18/group-shut-lagos-assembly-slums-demolition/

Hove, M., Ngwerume, E. T. and Muchemwa, C. (2013). The Urban Crisis in Sub-Saharan Africa. Stability 2(1): 1-14, DOI: http://dx.doi.org/10.5334/sta.ap 
Ibeanu, O. 1998. Exiles in their own home: Internal population displacement in Nigeria. African Journal of Political Science 3, 2: 80-97.

Ibrahim, A. Z. 2016. Ethical issues in urbanization among the developing world: A case study of Nigeria. In Ukase, P. I., Akubor, E. O. and Onoja, A. I. Eds. Urbanization, security, and development issues in Nigeria 1914-2014, festschrift in honour of Professor Enoch Oyedele. Zaria: Ahmadu Bello University Press Limited. Pp. 250-274.

Ihonvbere, J. O. 2000. A recipe for perpetual crises: The Nigerian state and the Niger Delta question. In Raji, W., Ale, A. and Akinsola, E. Eds. Boiling point. Ikeja, Lagos: Committee for the Defence of Human Rights. Pp. 73-109.

Ilo, M. I. O. 2016. Challenges of urbanization in Nigeria: A study of Lagos State, 1945-2014. In Ukase, P. I., Akubor, E. O. and Onoja, A. I. Eds. Urbanization, security, and development issues in Nigeria 1914-2014, festschrift in honour of Professor Enoch Oyedele. Zaria: Ahmadu Bello University Press Limited. Pp. 290-323.

Ishay, M. 2004. What are human rights? six historical controversies. Journal of Human Rights 3(3): 359-371. DOI: $10.1080 / 1475483042000224897$

Iwuagwu, O. 2008. Igbo food economy up to 1990. In O. Njoku \& O. Iwuagwu Eds. Igbo Economic History. Ikeja: First Academic Publishers.

Jibril, M. A. and Abah, D. 2016. Challenges of urbanization in Makurdi in the 21st Century. In Ukase, P. I., Akubor, E. O. and Onoja, A. I. Eds. Urbanization, security, and development issues in Nigeria 1914-2014, festschrift in honour of Professor Enoch Oyedele. Zaria: Ahmadu Bello University Press Limited. Pp. 275-289.

Jowitt, A. 2004. Indigenous land grievances, customary land disputes and restorative justice. Journal of South Pacific Law, 8 (2): 1-7.

Levan, A. C. and Olubowale, J. 2014. 'I am here until development comes': Displacement, demolitions, and property rights in urbanizing Nigeria. African Affairs 113/452: 387-408. http://urban-africachina.angonet.org/sites/default/files/resource_files/afr_aff_lond-2014-carl_levan-387-408.pdf

Mann, K. 1991. Women, landed property, and the accumulation of wealth in early Colonial Lagos. Signs: Journal of Women in Culture and Society, 16 (4): 682-706.

Obasanjo, 0. 1978. Reform in Nigerian Land Tenure System. Address to the nation on March 29. National Archives Ibadan.

Ogunniyi, O. J. 2016. Challenges of urbanization and poor development in colonial Nigeria: A historical analysis. In Ukase, P. I., Akubor, E. O. and Onoja, A. I. Eds. Urbanization, security, and development issues in Nigeria 1914-2014, festschrift in honour of Professor Enoch Oyedele. Zaria: Ahmadu Bello University Press Limited. Pp. 356-370.

Okene, A. A. and Uadiale, M. 2016. "Pilfering the commons: The security and development implications of the threats posed by foreign companies land grabs in Africa." In Ukase, P. I., Akubor, E. O. and Onoja, A. I. Eds. Urbanization, security, and development issues in Nigeria 1914-2014, festschrift in honour of Professor Enoch Oyedele. Zaria: Ahmadu Bello University Press Limited. Pp. 324-355.

Okolie-Osemene, J. 2017. Public space as a site of political protest in Nigeria: The Nexus between Gani Fawehinmi Park and cabalocracy in the denouement of fuel subsidy imbroglio. In S. Shlipchenko, I. and Tyshchenko, Eds. Public Spaces and Its (Dis)contents. Kyiv: Vsesvit PH.

Okonkwo, E. C. 2013. A closer look at the management, revocation and compensation principles under the Nigerian land use act. Afe Babalola University: Journal of Sustainable Development Law and Policy 1 (1): 21-36.

Olukolajo, M. A., Ajayi, M. A. and Ogungbenro, T. M. 2014 Crisis induced internal displacement: The implication on real estate investment in Nigeria. Journal of Economics and Sustainable Development 5, 4: 39-48.

Patel, T. G. and Tyrer, D. 2011. Race, crime and resistance. London: Sage Publications Ltd.

The Post Express. 2000. Review of land use decree. Saturday December 30.

The Guardian. 2007. Key issues in the revision of the land use decree, 1978. Monday October.

Ukase, P. I. 2016. Benue State @ 40: Urbanizing without industrialization. In Ukase, P. I., Akubor, E. O. and Onoja, A. I. Eds. Urbanization, security, and development issues in Nigeria 1914-2014, festschrift in honour of Professor Enoch Oyedele. Zaria: Ahmadu Bello University Press Limited. Pp. 533-570. 